\title{
ON THE DENTITION OF THE SAND SHARK, Odontaspis taurus, FROM THE VICINITY OF CANANÉIA, BRAZIL
}

(Received in 8/5/1969)

\author{
Victor SADOWSKY
}

Instituto Oceanográfico da Universidade de São Pauto

\section{SYNOPSIS}

Variation in the tooth distribution pattern and number of teeth is described from 528 jaws of the mangona or sand shark, Odontaspis taurus, from the vicinity of Cananéia, Brazil. On the basis of dental characteristics, this series gives no support to the recognition of more than one species of the shallow-water inhabiting sharks known variously over the world as sand sharks, mangonas, sardas, squalos toros, or grey nurse sharks. Counts of the teeth of 12 females and the two embryos contained in each of them show a considerable variation within each family group.

\section{INTRODUCTION}

The dentition of sharks represents an important taxonomic character, generally adopted for classification and identification. The remarkable variations of the total number of teeth, of the intermediate teeth and of the basal denticles found in the mangona or sand shark Odontaspis taurus (RAFINEsque, 1810) constitute a continuous problem. The sand sharks of the North American Atlantic coast were described several times as distinct from those of Mediterranean, but GARMAN (1913) recognized the so-called American species as identical with the European $O$. taurus and placed the specific names of the former on the list of synonyms of the latter. Later, GiLTAY (1933), noting differences in the dentition of the examined material, suggested the validity of the North American species, repeating the opinion of JoRDAN \& Evermann (1896) on the question. The detailed studies undertaken later by Bigelow \& Schroeder (1948; 1953) on the selachians of the western North Atlantic confirmed the conclusions of GARMAN concerning the sand sharks. However, recently CADENAT (1963) compared the data given by Bigelow \& Schroeder (1948), the results of his examination of a jaw from the West Atlantic, the data obtained from 8 North African (Senegal) specimens and again raised the question of the identity of the Euro-African with the North Atlantic sand sharks. Based upon certain differences in the dentition, CADENAT admits

Publ. n.o 291 do Inst, Ocean. da USP. the possibility of using them "to separate at least two forms of Carcharias taurus, C. taurus Raf., 1810, from Europe, and $C$. $t$. littoralis Lesueur, 1817, from North America". According to opinion 723 of the International Comission of Zoological Nomenclature, the generic name Odontaspis Agassiz, 1838, replaces the name Carcharias RaFinesQue, 1809.

As there are pratically no studies on the species from the Southwest Atlantic and as I had the opportunity to examine a rather large collection from this region (Instituto Oceanográfico, Cananéia), I add the data thus obtained from a population nearest to those of the East and Northwest Atlantic already mentioned hoping to contribute towards the solution of the problem.

\section{MATERIAL AND METHODS}

The jaws in the collection of the Oceanographic Station at Cananéia were brought together during the years 1962-1968 in the months October to June, the period of occurrence of migratory shoals of the species in the littoral zone of the sand bar off Cananéia (about lat. $25^{\circ} 1^{\prime} \mathrm{S}$, long. $47^{\circ} 52^{\prime} \mathrm{W}$ ). All specimens were in the reproductive stage, about $95 \%$ being females (SADOWSKY, 1967).

After the morphometric examination of the specimens the jaws were exsected, preserved in formol $10 \%$ for one or two weeks, and then dried in the sun. 
This procedure makes the study of the jaw easy, because the gums around the teeth shrink as an effect of drying. The material was still in perfect condition, to exclude the possibility of loss of some teeth. Due to the lack of adequate space only part of the studied jaws could be preserved definetively for the collection. They received a supplementary treatment with formol $40 \%$ and were coated with varnish. The terminology of the teeth corresponds, with certain exceptions, to that proposed by Applegate (1965).

\section{RESULTS}

The examined jaws belonged to 528 specimens of sand sharks. I noted a wide range of variation in the total number of teeth from 33 to 53 upper and 30 to 44 lower teeth (Table I). Frequently one half of the maxilla or mandible, palatoquadrate and cartilage of Meckel, respectively, had a number of teeth quite different from the other. Symmetrical numbers were registered only in 134 jaws, $25.38 \%$ of the total.
The arithmetical mean of the number of teeth in the dental formula is $40.3 \pm 2.41$ for the maxillar teeth and $37.2 \pm 2.34$ for those of the mandible. The most frequently registered combinations of the numbers in the dental formula were 38 to 42 for the upper and 35 to 39 for the lower teeth. The 25 combinations of these values represent $76.33 \%$ for the upper and $73.33 \%$ for the lower jaw. The most frequent combinations (modes) of upper and lower teeth in decreasing order are: 39 with 36 $(4.5 \%) ; 41$ with $38(4.2 \%)$, and 41 with 36 $(4.0 \%)$, lesser percentages following.

The intermediate teeth ("eye teeth" of WhitLEy, 1950) are situated in the large interval formed between the third frontal and the first lateral tooth. This interval always maintains its relative size proportional to the upper jaw, independent of the variable number of rows of intermediate teeth in the space, which oscillates from zero to four on either side (Fig. 1 and 2).

TABLE I - Distribution of numbers of jaws according to the number of teeth per jaw NUMBER OF TEETH IN LOWER JAW

\begin{tabular}{|c|c|c|c|c|c|c|c|c|c|c|c|c|c|c|c|c|c|}
\hline & N. ${ }^{\circ}$ & 30 & 31 & 32 & 33 & 34 & 35 & 33 & 37 & 38 & 39 & 40 & 41 & 42 & 43 & 44 & $\begin{array}{c}\text { Total } \\
\text { of jaws }\end{array}$ \\
\hline \multirow{7}{*}{$\sum_{3}^{3}$} & 33 & . & . & . & . & . & . & . & . & . & 1 & . & . & . & . & . & 1 \\
\hline & 34 & 2 & . & . & 1 & . & . & . & . & . & . &. &. & . & . & . & 3 \\
\hline & 35 & . & . & . & 2 & 1 & . & 1 & . & . & 1 & . & . & . & . & . & 5 \\
\hline & 36 & . & . & 1 & 2 & 2 & 5 & 2 & . & . & 1 & . & . & . & . & . & 13 \\
\hline & 37 & . & . & . & 3 & 8 & 5 & 4 & 3 & 4 & 2 & . & . & . & . & . & 29 \\
\hline & 38 & . & . & 1 & 3 & 9 & 14 & 8 & 11 & 10 & 4 & 1 & . & . & . & . & 61 \\
\hline & 39 & . & 1 & 1 & . & 10 & 11 & 24 & 12 & 15 & 0 & 1 & . & 1 & . & . & 85 \\
\hline 营 & 40 & . & . & 1 & 2 & 5 & 6 & 16 & 15 & 15 & 17 & 9 & 2 & 1 & 1 & 1 & 90 \\
\hline S & 41 & . & . & . & 1 & 5 & 10 & 21 & 18 & 22 & 15 & 8 & 3 & 1 & . & . & 104 \\
\hline \multirow{3}{*}{ 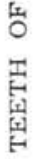 } & 42 & . & . & . & . & 2 & 3 & 10 & 12 & 17 & 7 & 6 & 2 & 3 & 1 & . & 63 \\
\hline & 43 & . & . & . & . & 1 & . & G & 2 & 3 & 9 & 5 & 5 & . & 2 & . & 33 \\
\hline & 44 & . & . & . & . & . & 2 & 2 & 1 & 2 & 1 & 4 & . & 2 & . & . & 14 \\
\hline \multirow{9}{*}{ 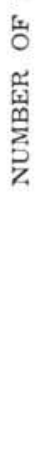 } & 45 & . & . & . & . & . & . & 1 & 1 & 2 & . & 5 & 2 & 1 & 1 & 3 & 16 \\
\hline & 46 & . & . & . & . & . & 1 & 1 & . & 1 & 1 & 1 & . & . & . & . & 5 \\
\hline & 47 & . & . & . & . & . & . & . & . & . & 1 & 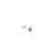 & . & . & 1 & . & 2 \\
\hline & 48 & . & . & . & . & . & . & . & . & . & . & , & . & . & . & . & 0 \\
\hline & 49 & . & . & . & . & . & . & . & . & . & . & . & . & 1 & . & 1 & 2 \\
\hline & 50 & . & . & . & . & . & . & . & . & . & . & . & . & . & . & . & 0 \\
\hline & 51 & . & . & . & . & . & . & . & $\cdot$ & . & . & . & . & . & . & . & 0 \\
\hline & 52 & . & . & . & . & . & . & . & . & . & . & . & . & . & . & 1 & 1 \\
\hline & 53 & . & . & . & . & . & . & . & . & . & . & . & . & . & 1 & . & 1 \\
\hline \multicolumn{2}{|c|}{$\begin{array}{l}\text { Total } \\
\text { of jaws }\end{array}$} & 2 & 1 & 4 & 14 & 43 & 57 & 96 & 75 & 90 & 69 & 40 & 14 & 10 & 7 & 6 & 528 \\
\hline
\end{tabular}




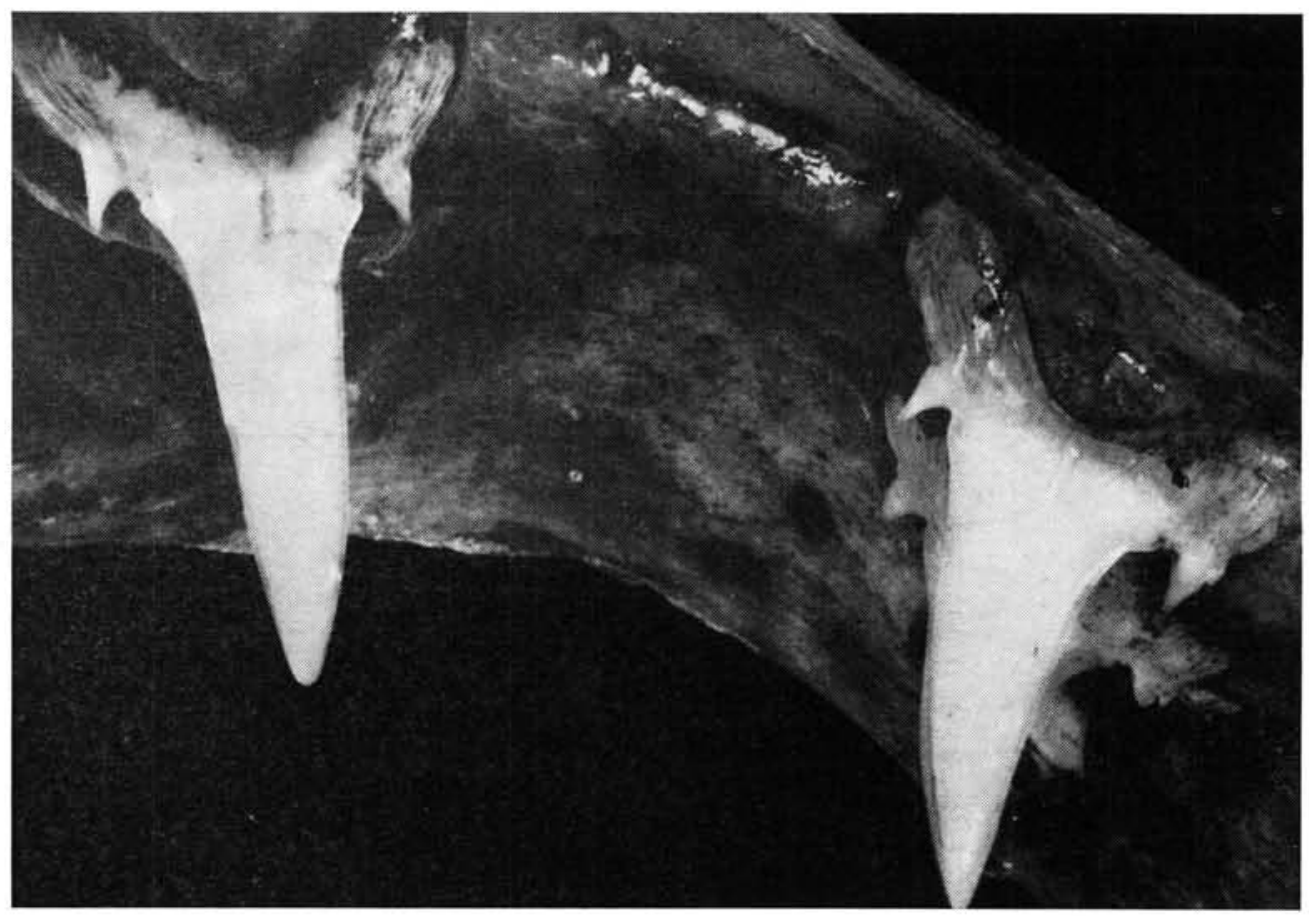

Fig. $\mathbf{I}$ - Gap in upper jaw without intermediate teeth.

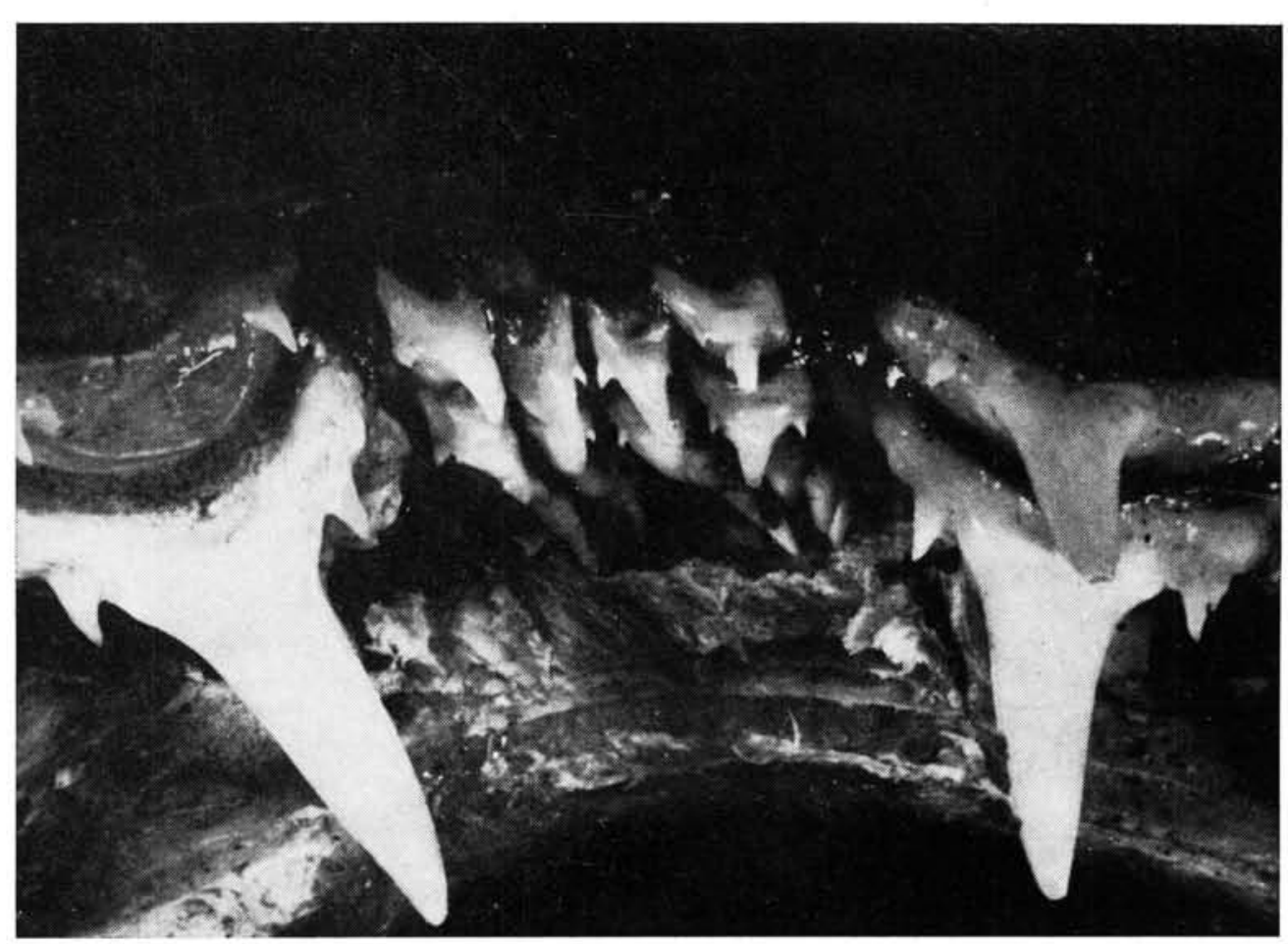

Fig. 2 - Gap in upper jaw with 4 intermediate teeth.

Table II gives the distribution of frequencies of number of these teeth separated into 5 groups. The first figure means the number of teeth on the right side, the second those on the left side of the jaw.

The occurrence of a symmetrical distribution of the intermediate teeth on both sides of the jaw was found in 372 cases, $70.4 \%$ of the total of collected jaws. These teeth are of rudimentary character and show highly varied sizes and shapes. In rare cases one or two functional teeth were missing in the row.

The basal denticles were present in the normal number, that is, one on either side of the cusp, in 491 jaws $(93 \%)$. In the remaining jaws denticles varied from zero to two $(0-2)$ on either side of the 
Number

of teeth: on right side

on left side

$$
\begin{aligned}
& : \frac{2}{4} \frac{4}{1} \frac{3}{3} \frac{3}{2} \frac{2}{3} \frac{3}{1} \frac{1}{3} \frac{2}{2} \quad \frac{2}{1} \frac{1}{2} \frac{2}{0} \quad \frac{1}{1} \quad \frac{0}{1} \frac{1}{0} \frac{0}{0}
\end{aligned}
$$

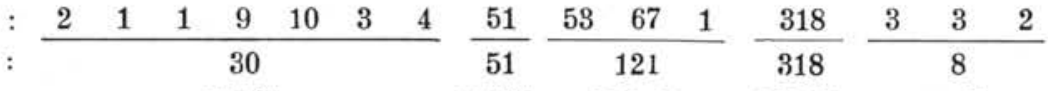

Totals in groups

Percentage

main cusp, or misshapen denticles were present. In 4 cases the frontals of the first series of the rows possessed normal denticles, while in the following series these were missing, or they were only visible as insignificant deformations on the base of the cusp, as shown in Figure 3. pends upon the subjective opinion of the examiner. The posterior laterals are of rudimentary aspect and of great variation as to number and shape. Their distribution is generally asymmetrical, and often anomalies occur in the shape, as well as lack of some teeth in the series.

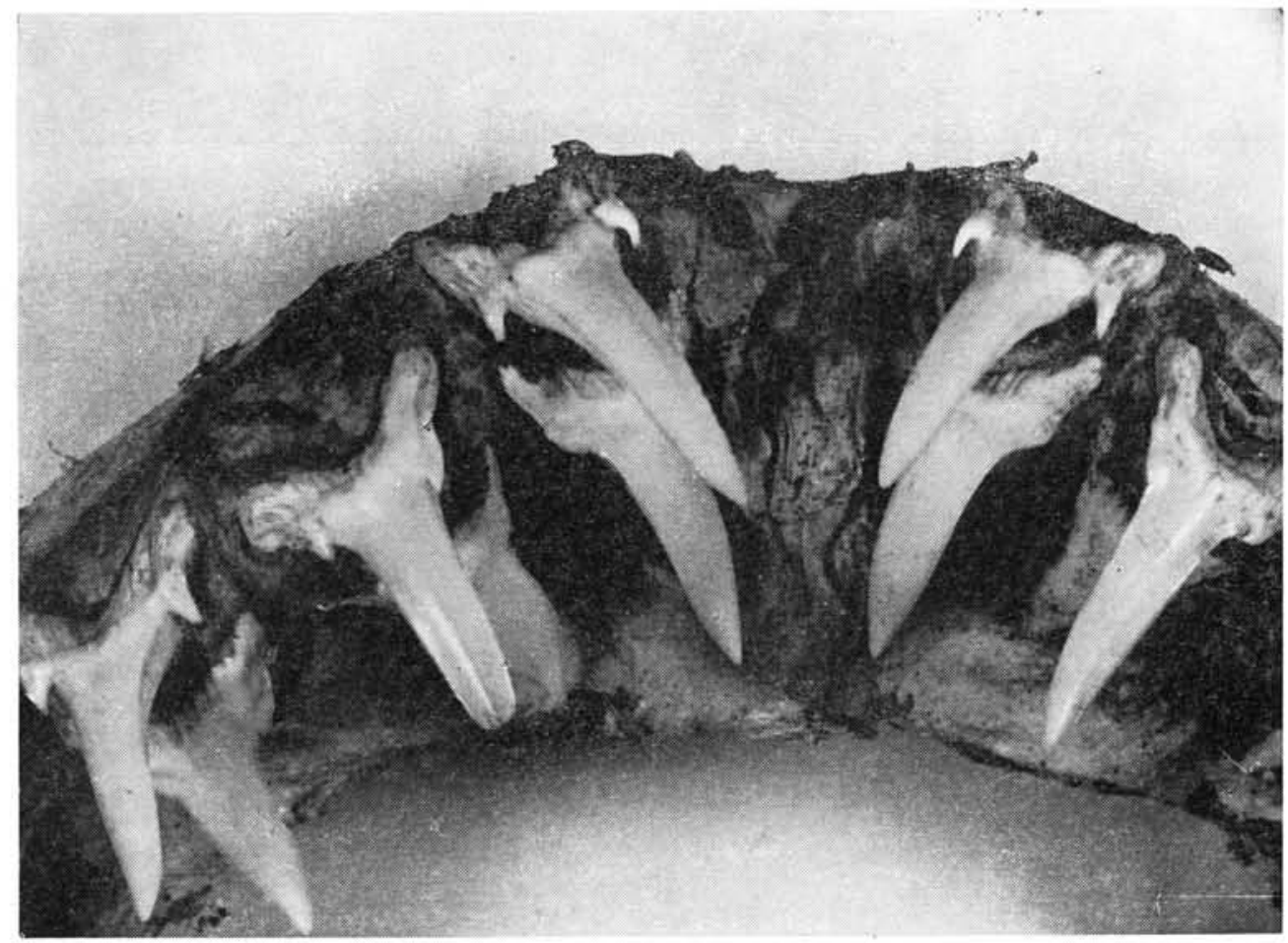

Fig. 3 - Frontal teeth of upper jaw with normal basal denticles in the first row, which are wanting or misshapen in the second.

The symphyseal and frontal teeth were always constant in number. The second or third row was lacking in 2 jaws. This phenomenon must evidently be attributed to an accident or an anomaly. The size and shape of the symphyseal teeth varied.

The anterior lateral and posterior lateral teeth showed a greater variability of their numbers, size and shape. Their separation into lateral and posterior, as proposed by Applegate (1965), does not seem to me to be sufficiently established, as there is no clear-cut separation between the last lateral and posterior teeth. The sizes of these decrease gradually towards the articulations, so that their distinction de-
For all teeth of the set it was noted that their size is directly correlated with the length of the sharks, and that the measurements are very similar to those presented by Applegate (1965) for O. taurus, and by LAHILLE (1928) for Odontaspis platensis Lah.. Moreover, no differences of the dentition were recorded which might be due to sexual dimorphism.

Thus the arrangement, shape, and position of the teeth correspond perfectly to the descriptions, the instructive drawings and photographs of the teeth of specimens from the Northwest Atlantic (Bigelow \& Schroeder, 1948; 1953; Applegate, 1965), from the Northeast Atlantic (Müller \& Henle, 1841), 
from the East Atlantic (Cadenat, 1956; 1963), and from the Southwest Indian Ocean (d'Aubrey, 1964). The same congruity is found with relation to the Argentinian $O$. platensis LAHILLE and the Australian $O$. arenarius Ogilby (Kemp's photograph in a letter of November 3, 1969).

Furthermore the teeth sets of the various migratory shoals of sand sharks were compared. As the results of this study were relatively uniform, the description of the results of one examination may be taken as a typical example.

On April 3, 1962, a shoal of 19 females of taurus, all in almost identical phases of pregnancy, furnished the following data: the variation of the total number of teeth was 37 to 45 in the upper and 34 to 39 in the lower jaw. The number and distribution of the intermediates was: in 13 specimens $(68.3 \%)$ $1 / 1$, in 3 specimens $(15.8 \%) 2 / 1$ or $1 / 2$, and the 3 remaining showed $2 / 2,3 / 2,2 / 4$, respectively. One specimen had an irregular number of basal denticles.

Therefore I investigated the apparently heterogeneous composition of the shoals. The jaws of 12 pregnant females pertaining to different migratory shoals and their embryos were examined. The number of teeth in each family group varied, but the difference was not greater than five teeth in the upper and three in the lower jaw. In 9 cases the variation of the number of intermediate teeth was up to three, and in the remaining 3 cases the teeth of the family group were uniform, with the most common combination $1 / 1$ (Table III).

As the embryonic teeth do not have any basal denticles, this character cannot be considered. All teeth are situated more or less slanting into the mouth cavity, except for the posterior laterals, the position of which is similar to that in adult specimens.

\section{DISCUSSION}

The comparison of the dental characters of the mangonas in the Cananéia population with those from other geographic occurrences of the species is rendered difficult by the fact that the data in many of the publications, even in the specialized literature, are scanty, incomplete, or not precise. Several references are based upon only one or few specimens, so that one cannot accept their characters without restriction as being representative of the entire population of a region. When few data are taken from a large population they may be quite different, but, when many data concerning the dentition of sand sharks are studied from populations of different areas, they are found to be homogeneous within certain limits of variation as graph 1 shows. As an exemple I give the data on the dentition concerning the relatively well known area of the northwestern coast of the Atlantic. In this region the range of the dental formula was modified every time the studies increased the data obtained by new observations. Thus in the monograph of GARMAN (1913) the formula was 40. 46/36-40, in Bigelow \& Schroeder (1948) it was 44-48/41-46, and Applegate (1965), based upon 12 jaws, gives $38-54 / 34-44$. If we add the data of
TABLE III - Numbers of teeth of pregnant females and their respective embryos

\begin{tabular}{|c|c|c|c|c|c|c|}
\hline N.o & Date & & & $\begin{array}{l}\text { Total } \\
\text { length } \\
(\mathrm{mm})\end{array}$ & $\begin{array}{c}\text { Number } \\
\text { of } \\
\text { teeth }\end{array}$ & $\begin{array}{c}\text { Number } \\
\text { of } \\
\text { inter- } \\
\text { mediate }\end{array}$ \\
\hline \multirow[t]{3}{*}{1.} & \multirow[t]{3}{*}{$1-5-1964$} & female & & 2256 & $40 / 37$ & $1 / 1$ \\
\hline & & embryo & $d$ & 520 & $38 / 36$ & $2 / 2$ \\
\hline & & embryo & † & 501 & $39 / 34$ & $1 / 2$ \\
\hline \multirow[t]{3}{*}{2.} & \multirow[t]{3}{*}{$1-5-1964$} & female & & 2380 & $42 / 39$ & $1 / 2$ \\
\hline & & embryo & $\sigma^{*}$ & 535 & $38 / 35$ & $1 / 1$ \\
\hline & & embryo & ๆ & 516 & $40 / 36$ & $1 / 1$ \\
\hline \multirow[t]{3}{*}{3.} & \multirow[t]{3}{*}{$1-5-1964$} & female & & 2334 & $40 / 36$ & $1 / 1$ \\
\hline & & embryo & 우 & 641 & $41 / 34$ & $1 / 1$ \\
\hline & & embryo & @ & 583 & $37 / 33$ & $1 / 1$ \\
\hline \multirow[t]{3}{*}{4.} & \multirow[t]{3}{*}{$1-5-1964$} & female & & 2520 & $37 / 37$ & $0 / 1$ \\
\hline & & embryo & q & 567 & $40 / 36$ & $2 / 2$ \\
\hline & & embryo & $\delta$ & 528 & $39 / 37$ & $1 / 1$ \\
\hline \multirow[t]{3}{*}{5.} & \multirow[t]{3}{*}{$18-4-1965$} & female & & 2480 & $39 / 39$ & $1 / 1$ \\
\hline & & embryo & $0^{*}$ & 605 & $38 / 37$ & $1 / 1$ \\
\hline & & embryo & $\sigma^{\circ}$ & 611 & $40 / 39$ & $1 / 1$ \\
\hline \multirow[t]{3}{*}{6.} & \multirow[t]{3}{*}{$18-4-1965$} & female & & 2284 & $41 / 39$ & $2 / 3$ \\
\hline & & embryo & 8 & 574 & $43 / 38$ & $2 / 2$ \\
\hline & & embryo & $\sigma^{\circ}$ & 569 & $39 / 37$ & $1 / 1$ \\
\hline \multirow[t]{3}{*}{7.} & \multirow[t]{3}{*}{$27-4-1967$} & female & & 2377 & $41 / 38$ & $1 / 1$ \\
\hline & & embryo & ㅇ & 585 & $41 / 36$ & $2 / 1$ \\
\hline & & embryo & $\sigma^{\circ}$ & 569 & $40 / 36$ & $1 / 1$ \\
\hline \multirow[t]{3}{*}{8.} & \multirow[t]{3}{*}{$27-4-1967$} & female & & 2354 & $38 / 35$ & $2 / 1$ \\
\hline & & embryo & 우 & 675 & $37 / 34$ & $1 / 1$ \\
\hline & & embryo & ㅇ & 667 & $39 / 34$ & $2 / 1$ \\
\hline \multirow[t]{3}{*}{9.} & \multirow[t]{3}{*}{$27-4-1967$} & female & & 2416 & $39 / 36$ & $1 / 1$ \\
\hline & & embryo & $\sigma^{\prime}$ & 590 & $40 / 36$ & $1 / 1$ \\
\hline & & embryo & ㅇ & 587 & $37 / 33$ & $1 / 1$ \\
\hline \multirow[t]{3}{*}{10.} & \multirow[t]{3}{*}{$31-5-1968$} & female & & 2450 & $39 / 38$ & $1 / 2$ \\
\hline & & embryo & $\sigma^{\circ}$ & 642 & $38 / 38$ & $1 / 1$ \\
\hline & & embryo & $\sigma^{\circ}$ & 640 & $40 / 37$ & $2 / 1$ \\
\hline \multirow[t]{3}{*}{11.} & \multirow[t]{3}{*}{$31-5-1968$} & female & & 2315 & $42 / 37$ & $2 / 2$ \\
\hline & & embryo & 8 & 730 & $41 / 37$ & $1 / 1$ \\
\hline & & embryo & ㅇ & 702 & $41 / 35$ & $1 / 2$ \\
\hline \multirow[t]{3}{*}{12.} & \multirow[t]{3}{*}{$31-5-1968$} & female & & 2335 & $40 / 39$ & $1 / 1$ \\
\hline & & embryo & 우 & 800 & $41 / 37$ & $1 / 1$ \\
\hline & & embryo & $\sigma^{\circ}$ & 782 & $42 / 39$ & $2 / 1$ \\
\hline
\end{tabular}

Springer (1938), which are 40-46/31-43, the dental formula for the Northwest Atlantic population is, in 1968 , 38-54/31-46, hence, the amplitude of oscillation between the extreme values became considerably greater than in Garman's original iormula. On the cther hand, it became more like the formulae found in other regions, e.g., that of Cananéia, and that of Durban-Natal, South Africa (personal communication from Dr. J. D'Aubrey). The information concerning other geographic regions is less representative and evidently constitutes only fragments of the dental formula as in: Müller \& Henle (1841), Soljan (1948), Cadenat (1963), for the Mediterranean; Cadenat (1963), for Senegal; Barnard (1925) and Cadenat (1963) for South Africa; Chen (1963) for Taiwan; and Berg (1895), LAhille (1928), and SicCARDI (personal communication), in the species $O$. platensis, for Argentina. 


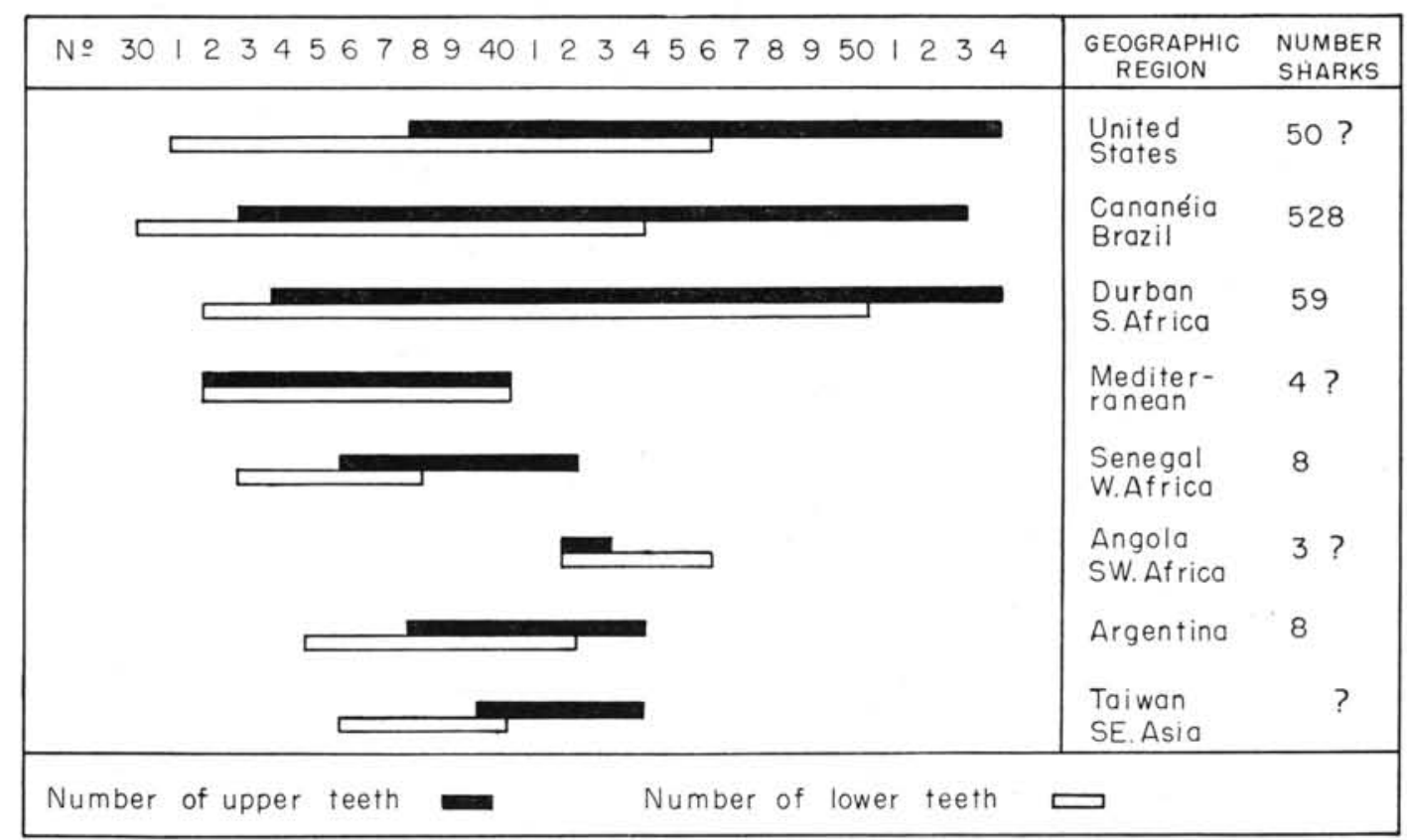

Graph 1 - Distribution of extreme values of total number of teeth of sand sharks of different origin.

The variation in the number of intermediates for the type locality, the Mediterranean, is given as $1 / 1,1 / 2$, and $2 / 1$; in the other regions these combinations are: in the northwestern Atlantic 100\%, (all of which 1/1); in southern Brazil $83.1 \%$, $(60.1 \%$ of which $1 / 1)$; in Natal, South Africa $79.6 \%,(55.5 \%$ of which $1 / 1)$. The uniformity of this dental character in the population from the North American coast is of minor importance, as the Brazilian population $(60,1 \%)$ shows the same combination. It could be due to the isolation of the population. But, these populations are not isolated as is proved by the occurrence of $O$. taurus in the circum. tropical region, in the open ocean (lat. $1^{\mathrm{C} S}$, long. $23^{\circ} \mathrm{W}$ ), and in the Caribbean (Tortonese, 1939; SPringer, 1950; Zaneveld, 1961). In a recent paper Applegate (1965) mentions a jaw in the Museum of the Duke University with missing intermediates $(0 / 0)$. This does not exclude the possibility, that with an increasing number of specimens studied in detail, also combinations of intermediates might appear in this region, which hitherto has not been observed.

The dentition of the members of the Cananéia population is characterized by 15 combinations in which the intermediates go from $0 / 0$ to $2 / 4$. This last combination represents a case not yet registered.

The South African population (Natal) shows 6 combinations, from $1 / 1$ to $3 / 2$. These variations are very similar to those registered at Cananéia.

\section{CONCLUSIONS}

The data recorded in most regions permit the conclusion that an irregular number of basal denticles is a character of no taxonomic importance for the species.
The studies at Cananéia permit the conclusion that the migratory shoals in this region are always composed of specimens with mixed dental characters. Moreover, the different numbers in the dental formulae of the pregnant females and their embryos furnish, to my view, sufficient proof that the shoals are not composed of individuals of various constantly different dental characters but of specimens in which the variability of the dental elements constitutes a hereditary character.

Based on the dentition of the sand sharks of the coast of Southern Brazil I feel justified in concluding that they are not a form distinct from the cosmopoli$\tan$ Odontaspis taurus. When the dentitions of the Southwest Atlantic sand sharks are compared with those better studied of the North American and Indian Ocean, the differences consist mainly in the percentage of specimens with different dental characters taken at random as representatives of the respective population.

\section{SUMMARY}

The results of the study of 528 jaws of sand sharks from the vicinity of Cananeiia are given. The dental formula is 33-53/30-44; the arithmetical mean is $40 \pm 2.41 / 37.2 \pm 2.34$. 15 combinations of intermediate teeth of the upper jaw from 0 to 4 on either side are present in the following percentages: $1.5 \%$ $(0 / 0,0 / 1,1 / 0) ; 60.2 \%(1 / 1) ; 22.9 \%(1 / 2,2 / 1,2 / 0)$; $9.7 \%(2 / 2) ; 5.7 \%(1 / 3,3 / 1,2 / 3,3 / 2,3 / 3,4 / 1,2 / 4)$.

Anomalies in number and shape of the basal denticles were observed in $7 \%$ of the total numbers of jaws.

The shoals are always composed of specimens with varied dental formulae. The variability of the dental characters was found to be hereditary.

The comparison of the dentition of the sand sharks from different regions based upon the data in the specialized literature results in the conclusion, 
that in the southwestern Atlantic, the separation of a distinct form of Odontaspis taurus, on the basis of dental characteristics, is not justified.

\section{RESUMO}

Examinei 528 dentaduras de mangonas, provenientes da região de Cananéia. A fórmula dental é

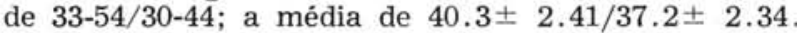
15 combinações dos dentes intermediários na maxila são de 0 até 4 de cada lado, em percentagens: $1.5 \%$ $(0 / 0,0 / 1,1 / 0) ; 60.2 \%(1 / 1) ; 22.9 \%(1 / 2,2 / 1,2 / 0)$ $9.7 \%(2 / 2) ; 5.7 \%(1 / 3,3 / 1,2 / 3,3 / 2,3 / 3,4 / 1,2 / 4)$.

Anomalias em número e forma dos dentículos basais foram observadas em $7 \%$ do número total das dentaduras.

Os cardumes são sempre compostos por especimens de fórmula dentária variada. A variabilidade dos caracteres dentais é considerada como hereditária.

A comparação das dentições de mangonas de várias regiões, baseada nos dados existentes na literatura especializada, resultou na conclusão de que não se justifica a separação de uma forma distinta do Odontaspis taurus no SW Atlântico.

\section{ACKNOWLEDGEMENTS}

My thanks are due to Mrs. Eveline Marcus for the translation of the manuscript, to Dr. Stewart Springer, Bur. of Comm. Fish. Ichtyological Laboratory U.S. Nat. Mus. Washington, who read the manuscript and offered valuable criticisms, to Drs. Elvira Siccardi, University of Buenos Aires, and Jeanette d'Aubrey, Oceanographic Research Institute Dur. ban, for the data furnished, to Mr. Noel Kemp, University of Melbourne, Australia, for a good photograph of the teeth of $O$. arenarius, and to Mr. Renato Herz, Oceanographic Institute S. Paulo, for the photographs.

\section{R E F E R E N C E S}

Applegate, $\mathrm{S}$

1965. Tooth terminology and variation in sharks with special reference to the sand shark, Carcharias taurus Rafinesque. Contr. Sci. Los Angeles Co. Mus. vol. 86 , p. $3-18$

BARNARD, $\mathrm{K}$

1925. A monograph of the marine fishes of South Africa. Ann. S. Afr. Mus., vol. 21 , part 1 , p. $1-60$

Berg, C.

1895. Enumeracion sistematica y sinonimica de los peces de las costas Argentina y Uruguaya. An. Mus, nac. Hist. nat. $B$ Aires, vol. 4, p. 1-120.

Bigelow, H. \& Schoeder, W.

1948. Fishes of the Western North Atlantic. Mem. Sears Fdn mar. Res., vol. 1, n. 1 , p. $59-576$.

1953. Fishes of the Gulf of Maine. Fishery Bull. Fish Wildl. Serv. U.S., vol. 74, n. ${ }^{\circ} 53$, p. $1-577$.
Cadenat, J.

1956. Note d'ichtyologie ouest-africaine. XIV. Remarques biologiques sur le requin-sable Carcharias (Odontaspis) taurus Rafinesque 1810. Bull. Inst. fr. Afr. noire, vol. 18 , Ser. A, n. ${ }^{4}$, p. 1249-1256.

1963. Notes d'ichtyologie ouest-africaine. XXXIX. Notes sur les requins de la famille des Carchariidae et formes apparentes de l'Atlantique ouest-africain (avec la description d'une espèce nouvelle: Pseudocarcharias pelagicus, classée dans un sous-genre nouveau). Bull. Inst. fr. Afr. noire, vol. 25, Ser. A, n. ${ }^{2}$, p. $526-537$.

CHen, J.

1963. A review of the sharks of Taiwan. Biol. Bull. Coll. Sci. Tunghai Univ., Ichthyol. Ser., n. ${ }^{\circ}$, p. 1-102.

D'AUBrey, J

1964. Preliminary guide to the sharks found off the east coast of South Africa. Invest. Rep. oceanogr. Res. Inst., vol. 8, p. 1-95

Fowler, $\mathrm{H}$

1936. The marine fishes of West Africa . Bull. Am. Mus. nat. Hist., vol. 70, part 1, p. 1-605.

GARMAN, S.

1913. The Plagiostomia (sharks, skates and rays). Mem. Mus. comp. Zool. Harv., vol. 36 , p. 1-528.

Giltay, L.

1933. Résultats scientifiques du voyage aux Indes Orientales Néerlandaises de LL.AA.RR. le Pr, et la Princ. Leopold de Belgique. Mém. Mus. r. Hist. nat. Belg., Ser. 5, n. ${ }^{\circ}$ 3, p. 1-129.

\section{INTERNATIONAL COMMISSION}

ON ZoOlogical Nomenclature

1965. Bull. zool. Nom., vol. 22, n. ${ }^{0} 1$, p. 32-36.

JORDAN, D. \& EVERMANN, B.

1896. The fishes of North and Middle America. Bull. U.S. natn. Mus., vol. 47, n. ${ }^{\circ} 1$, p. $1-1240$.

LAHILLE, F.

1928. Nota sobre unos peces Elasmobranquios. An. Mus. nac. Hist. Nat. "Bernardino Rivadavia", vol. 34, n. $^{\circ} 12$, p. 229-239 .

MÜlLeR, J. \& HeNle, J.

1841. Systematische Beschreibung der Plagiostomen. Berlin, Verlag Veit und Comp., 204 p., 60 plates.

RIBEIRo, A. M.

1923. Fauna Brasiliense - Peixes. Reed. of Archos Mus. nac. Rio de J., vol. 2, n. $^{\circ}$ 1 , p. $1-50$ b.

SADowsky, V.

1967. Selachier aus dem Litoral von São Paulo, Brasilien. Beitr. neotrop. Fauna, vol. 5, n. ${ }^{\circ} 2$, p. $71-88$.

SOLJAN. T.

1963. Fishes of the Adriatic. Translated by M. Hayer. Belgrade, Nov, Ed., 428 p. (Edição original editada em 1948). 
SPRINGER, S.

1938. Notes on the sharks of Florida. Proc. Fla Acad. Sci., vol. 3, p. 9-41.

1950. An outline for a Trinidad shark fishery. Proc. Gulf Caribb. Fish. Inst., Second ann. Session, p. 17-26.

TORTONESE, E.

1939. Resultati ittiologici del viaggio di circumnavigazione del globo dela $\mathrm{R}$. N. Magenta (1865-68). Boll. Musei Zool.
Anat. comp. R. Univ. Torino, vol. 47, n. ${ }^{\circ}$, p. 1-66.

Whitley, G.

1950. Studies in ichthyology. 14. Rec. Aust. Mus., vol. 22, n. ${ }^{\circ}$, p. 234-245.

ZANEVELD, J.

1961. The fishery resources and the fishery industries of the Netherlands Antilles. Proc. Gulf Caribb. Fish. Inst., Fourteenth ann. Session, p. 137-171. 